\title{
CORRECTION OF STRESS-INDUCED HORMONAL CHANGES BY THE RIL-2 MEDICATION IN EXPERIMENTAL TRAUMATIC BRAIN INJURY
}

\author{
E.E. Fomicheva ${ }^{1}$, S.N. Shanin ${ }^{1}$, T.A. Filatenkova ${ }^{1}$, N.B. Serebryanaya ${ }^{1,2,3}$ \\ ${ }^{1}$ Institute of Experimental Medicine, Saint Petersburg, Russia; \\ ${ }^{2}$ Saint Petersburg State University, Saint Petersburg, Russia; \\ ${ }^{3}$ North-Western State Medical University named after I.I. Mechnikov, Saint Petersburg, Russia

\section{КОРРЕКЦИЯ СТРЕСС-ИНДУЦИРОВАННЫХ ГОРМОНАЛЬНЫХ ИЗМЕНЕНИЙ ВВЕДЕНИЕМ RIL-2 ПРИ ЭКСПЕРИМЕНТАЛЬНОЙ ЧЕРЕПНО-МОЗГОВОЙ ТРАВМЕ}

\author{
Е.Е. Фомичева ${ }^{1}$, С.Н. Шанин ${ }^{1}$, Т.А. Филатенкова ${ }^{1}$, Н.Б. Серебряная ${ }^{1,2,3}$ \\ ${ }^{1}$ ФГБНУ «Институт экспериментальной медицины», Санкт-Петербург; \\ ${ }^{2}$ Санкт-Петербургский государственный университет, Санкт-Петербург; \\ ${ }^{3}$ ФГБОУ ВО «Северо-Западный государственный медицинский университет им. И.И. Мечникова» \\ Минздрава России, Санкт-Петербург
}

Traumatic brain injury (TBI) leads to steady stress reaction that may substantially influence on posttraumatic period. Stress changes concentration of sex hormones too, that play role of neurosteroids in CNS. The aim of the study was to detect changes in corticosterone and testosterone concentration in serum of experimental animals during recovery period after TBI. And also to find possibility of disturbance correction by cytokine preparation rIL-2 (ronkoleukin). After TBI both experimental and control group of animals get daily injections of recombinant human interleukin-2. TBI decreased the level of corticosterone on $30 \%$, the injection of rIL-2 increased it. Testosterone slightly changed after TBI. But it's level increased when after TBI the injections of rIL-2 were done. The obtained results can be considered as evidence of the stress reaction normalization in animals after TBI and under the conditions of their treatment with rIL-2.

Keywords: stress-hormones; TBI; rIL-2.

Черепно-мозговая травма (ЧМТ) приводит к устойчивой стресс-реакции, которая может существенно повлиять на посттравматический исход. Целью исследования было определение содержания кортикостерона $(\mathrm{Kc})$ и тестостерона $(\mathrm{Tc})$ в сыворотке крови животных в посттравматический период после ЧМТ и возможности коррекции нарушений цитокиновым препаратом rIL-2 (ронколейкин). После ЧМТ животным вводили препарат рекомбинантного человеческого интерлейкина-2 (rIL-2). ЧМТ на 30 \% снижала уровень Kc, а введение rIL-2 увеличивало его концентрацию. Концентрация Тс незначительно изменялась после ЧМТ, но возрастала в группе животных после ЧМТ и введения rIL-2. Полученный результат можно рассматривать как свидетельство нормализации стресс-реакции у травмированных животных в условиях их лечения rIL-2.

Ключевые слова: стресс-гормоны; ЧМТ; ронколейкин.

Introduction. Traumatic brain injury (TBI) leads to a sustained stress reaction, individual changes in the production of stress hormones and reactions to them can lead to different post-traumatic outcomes due to disruption of the mechanisms of neuro-endocrine-immune interaction [1]. The most important stress-regulating system is the hypothalamic-pituitary-adrenocortical system (HPA axis), its timely activation ensures adequate secretion of corticosterone and counteracts the development of excessive secondary inflammation. Stress also changes the activity of the hypothalamic-pituitary-gonadal system (HPGS), since sex hormones perform their specific roles in the process of adaptation during stress [2]. Testosterone and its metabolites play the role of neurosteroids In the central nervous system, their participation in the formation of training, memory and social behav- ioral motivation has been proven. [3]. The aim of the study was to detect changes in corticosterone and testosterone concentration in blood serum of experimental animals during recovery period after TBI. And also to find possibility of disturbance correction by cytokine preparation rIL-2 (ronkoleukin).

Material and methods. The study was perfomed on male Wistar rats weighing 250-300 g. A model of "falling weight" was used as a model of traumatic brain injury [2]. The weight of $115 \mathrm{~g}$ fell from a height of $120 \mathrm{~cm}$ to the center of the parietal part of the animal's head. After TBI the injections of a recombinant human interleukin-2 (rIL-2, Roncoleukin (BIOTECH, Saint Petersburg, Russia)) in dose of $30 \mathrm{mg} / \mathrm{kg}$ of weight were made to a group of animals, including the control group (without TBI), daily for three days. Measurement 
Changes in blood levels of corticosterone and testosterone on the $7^{\text {th }}$ day after the application of TBI and the injection of rlL-2

\begin{tabular}{|l|c|c|}
\hline \multirow{2}{*}{$\begin{array}{c}\text { Animal groups } \\
n=\mathbf{5}\end{array}$} & \multicolumn{2}{c|}{ Hormonal tests } \\
\cline { 2 - 3 } & Corticosterone $\mathrm{ng} / \mathrm{ml}$ & Testosterone $\mathrm{ng} / \mathrm{ml}$ \\
\hline Control & $70.0 \pm 10.0$ & $3.8 \pm 0.3$ \\
\hline TBI & $50.0 \pm 8.0$ & $5.3 \pm 0.5$ \\
\hline Control + rIL-2 & $160.0 \pm 25.0^{*}$ & $5.8 \pm 0.8$ \\
\hline TBI + rIL-2 & $220.0 \pm 40.0^{*, \#}$ & $8.0 \pm 0.8^{*}$ \\
\hline
\end{tabular}

Note. ${ }^{*} p<0.05$ in compared with hormone levels of intact animals; ${ }^{*} p<0.05$ in compared with hormone levels of animals after TBI.

of corticosterone (Cs) and testosterone (Ts) concentration in blood serum was made by ELISA kit (DRGDiagnostic). Statistical processing of materials was carried out using the Mann - Whitney test.

Results and discussion. Experiments were done on animals with moderate injury on the $7^{\text {th }}$ day after TBI. Concentration of hormones was measured, and it was shown that the level of corticosterone was decreased in blood serum up to $30 \%$ in compare with the control animals (table 1). Injection of rIL-2 to control animals (without TBI) increased the level of Cs in 2-3 times. This fact probably is the result of corticotropic action of IL-2. After the injection of rIL-2 animals in 72 hours after TBI, an additional increase in the Cs level was detected.

Conclusion. Ts slightly changed in animals on day 7 after TBI compared with this indicator in intact animals and control, that only got rIL-2 injections. But it's level increased when after TBI the injections of rIL-2 were done. The obtained results can be considered as evidence of the stress reaction normalization in animals after TBI. It is well known that levels of IL-2 and high-affinity receptor for IL-2 also change under the stress. Under mild stress they increase, and when acute stress, they are decreased [4]. Under stress, the activated HPA axis has a direct effect on the HPGS, entering into reciprocal relations with it. The lack of corticosterone secretion is the cause of increased secretion of $\mathrm{ACTH}$, which shifts steroidogenesis in the direction of excessive formation of deoxycorticosterone and inhibition of androgen production. It is well known that stress in animals causes suppression of testosterone synthesis, and the duration of action of a stressor is a determining factor for reducing its level [5]. So, the change in the functional activity of HPA axis and HPGS as stress systems for TBI under the influence of rIL-2 is important for the turning on of regulatory mechanisms aimed at overcoming the effects of acute inflammation (including TBI) in the post-traumatic period.

\section{References}

1. Rybakina EG, Shanin SN, Fomicheva EE, et al. Cellular molecular mechanisms of changes in the protective functions of the body in traumatic brain injury and an attempt at treatment. Medical Academic Journal. 2014;14(4):55-62.

2. Babichev VN. Neuroendocrine effect of sex hormones. Advances in physiological sciences. 2005;36(1):54-67.

3. Kubasov RV. Hormonal changes in response to extreme environmental factors. Vestnik of RAMS. 2014;9(10):102-110.

4. Beloshitsky VV. Modern principles of modeling traumatic brain injury in the experiment. Neuroscience. 2005;1(1):81-87.

5. Himmerich H, Fischer J, Bauer K, et al. Stress-induced cytokine changes in rats. Eur Cytokine Netw. 2013;24(2):97-103. 